\title{
Traumatic carotid-cavernous fistula combined with pseudoaneurysm requires immediate treatment
}

\author{
Johan A F Koekkoek, ${ }^{1}$ Geert J Lycklama à Nijeholt, ${ }^{2}$ Korné Jellema, ${ }^{1}$ \\ Rob Walchenbach ${ }^{3}$
}

'Department of Neurology, Medical Centre Haaglanden, Den Haag, The Netherlands ${ }^{2}$ Department of Radiology, Medical Centre Haaglanden, Den Haag, The Netherlands ${ }^{3}$ Department of Neurosurgery, Medical Centre Haaglanden, Den Haag, The Netherlands

\section{Correspondence to} Johan A F Koekkoek, j.koekkoek@mchaaglanden.nl

\section{DESCRIPTION}

A 69-year-old woman presented with recurrent episodes of heavy epistaxis after previous head trauma. She reported a slowly progressive left-sided headache, a slightly swollen left eye and pulsatile tinnitus for 3 weeks. Her medical history showed a cerebral concussion with multiple facial fractures after a fall from her bicycle 3 months ago. On neurological examination, she had slight chemosis and proptosis of the left eye, an intracranial bruit on auscultation over the left orbit and bilateral extensor plantar responses. CT of the brain showed obliteration of the left sphenoid sinus with a small defect in its lateral wall and dilation of the left superior ophthalmic vein (SOV). Contrastenhanced CT angiography (CT-A) clearly confirmed the dilation of the left SOV and enlargement of the left cavernous sinus. Furthermore, there was a pseudoaneurysm extending into the left sphenoid sinus (figure 1). Diagnostic cerebral angiography confirmed the diagnosis of a direct carotid-cavernous fistula (CCF). Because the patient did not tolerate an occlusion of the ipsilateral internal carotid artery (ICA) due to an insufficient anterior communicating artery, stent-assisted coiling of the left cavernous sinus was performed, after which the patient's symptoms improved and the pseudoaneurysm was obliterated (figure 2).

The most common type of CCF is the one connecting the ICA directly to the cavernous sinus, often caused by traumatic rupture of the ICA. SOV dilation, combined with bone fractures and obliteration of the sphenoid sinus, is a key radiological feature that can often be recognised on non-contrast-enhanced CT. Strong enhancement and enlargement of the cavernous sinus and SOV on CT-A, as well as the presence of a pseudoaneurysm, additionally support the diagnosis. Current
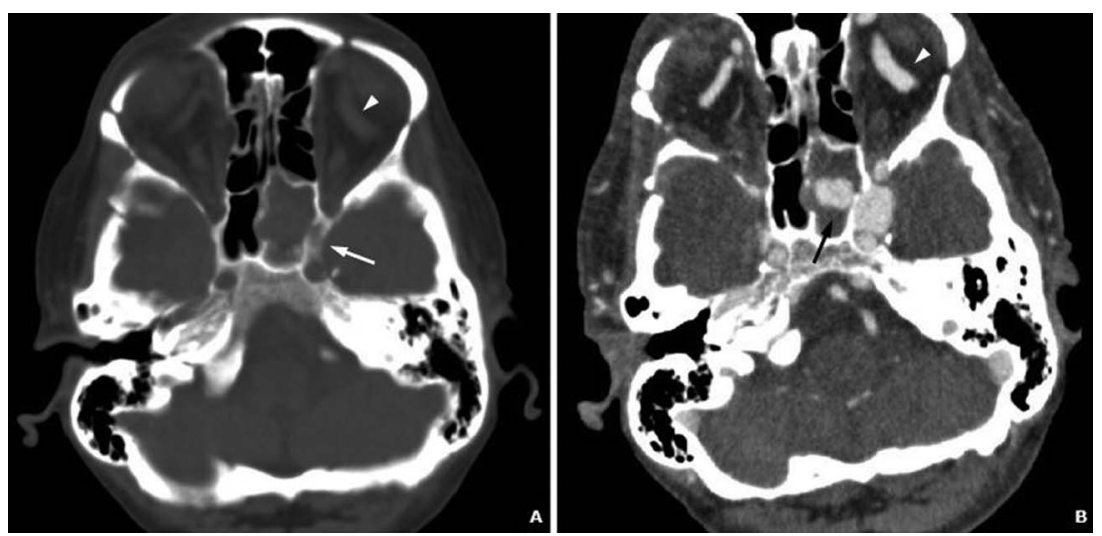

Figure 1 (A) Non-contrast-enhanced CT of the brain and facial bones showing dilation of the left superior ophthalmic vein (SOV) (arrowhead) and increased density of the left sphenoid sinus with a fracture of its lateral wall (white arrow); (B) contrast-enhanced CT-angiography showing dilation of the left SOV (arrowhead), enlargement of the cavernous sinus and a pseudoaneurysm protruding in the left sphenoid sinus (black arrow).

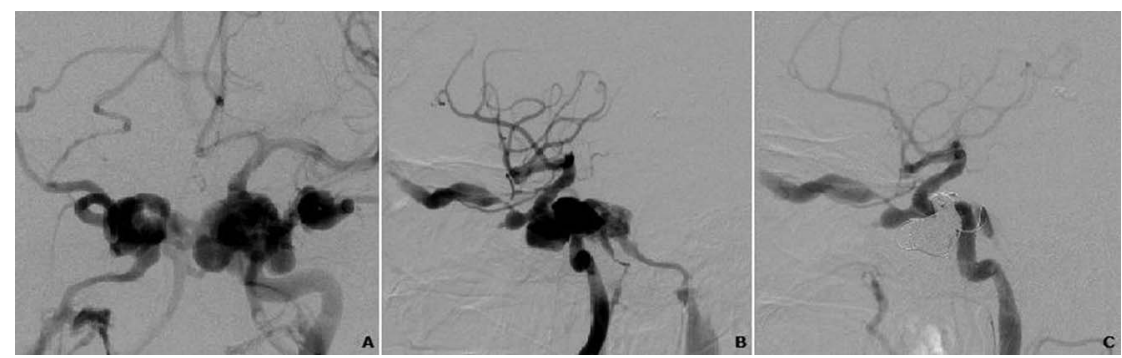

To cite: Koekkoek JAF, Lycklama à Nijeholt GJ, Jellema K, et al. BMJ Case Rep Published online: [please include Day Month Yearl doi:10.1136/bcr-2013009013 pseudoaneurysm projecting into the left side of the sphenoid sinus; (B) lateral view showing the dilation of the superior ophthalmic vein (SOV); (C) lateral view after coiling of the cavernous sinus showing significant reduction of the carotid-cavernous fistula. Dilation of the left SOV is still visible after initial treatment. 
therapeutic options consist of the occlusion of ICA, or endovascular embolisation of the fistula using detachable balloons or coils, often using intra-arterial stents. CCF with pseudoaneurysm may present with massive epistaxis, which requires urgent treatment. ${ }^{1} 2$ Therefore, early recognition is essential to prevent the development of severe complications such as massive blood loss, progressive proptosis, visual loss, intracranial or subarachnoid haemorrhage, cerebral ischaemia and death. ${ }^{3}$

\section{Learning points}

- A traumatic carotid-cavernous fistula (CCF) connecting the internal carotid artery directly to the cavernous sinus is a potentially life-threatening condition requiring urgent treatment, particularly in the presence of a pseudoaneurysm.

- Early recognition of clinical symptoms of CCF like epistaxis, proptosis and chemosis is essential to prevent severe complications.

- Enlargement of the superior ophthalmic vein on non-contrast-enhanced $\mathrm{CT}$, as well as dilation of the cavernous sinus and signs of a pseudoaneurysm on contrast-enhanced CT-A, is a key radiological feature associated with CCF that should not be missed.
Contributors All authors contributed to the conception and design, drafting of the article and revising it critically for important intellectual content and final approval of the version to be published.

Competing interests None.

Patient consent Obtained.

Provenance and peer review Not commissioned; externally peer reviewed.

\section{REFERENCES}

1 Huai RC, Yi CL, Ru LB, et al. Traumatic carotid cavernous fistula concomitant with pseudoaneurysm in the sphenoid sinus. Interv Neuroradiol 2008;14:59-68.

2 Ellis JA, Goldstein H, Connolly ES Jr, et al. Carotid-cavernous fistulas. Neurosurg Focus 2012;32:E9.

3 Halbach VV, Hieshima GB, Higashida RT, et al. Carotid cavernous fistulae. AJR Am J Roentgenol 1987;149:587-93.

Copyright 2013 BMJ Publishing Group. All rights reserved. For permission to reuse any of this content visit http://group.bmj.com/group/rights-licensing/permissions.

BMJ Case Report Fellows may re-use this article for personal use and teaching without any further permission.

Become a Fellow of BMJ Case Reports today and you can:

- Submit as many cases as you like

- Enjoy fast sympathetic peer review and rapid publication of accepted articles

- Access all the published articles

- Re-use any of the published material for personal use and teaching without further permission

For information on Institutional Fellowships contact consortiasales@bmjgroup.com

Visit casereports.bmj.com for more articles like this and to become a Fellow 